\title{
CHEEK-PIECES WITH ZOOMORPHIC IMAGES OF THE SAMARA-URAL REGION NOMADS IN THE VI-IV CENTURIES BC ${ }^{1}$
}

\author{
Vladimir N. Myshkin \\ Samara State Social and Pedagogical University, Samara, Russian Federation
}

\begin{abstract}
The article illustrates a study of cheek-pieces with zoomorphic images used by the nomads of the Samara-Ural region at the end of the VI-IV centuries BC. A review of 79 cheek-pieces is presented, as well as their characteristics. As a result of the excavations, two chronological groups of such horse gear are identified. The date of the early group refers to the second half of the VI-V centuries BC. It is characterized by rod-like straight and arcuate curved bronze, iron, bimetallic double-hole bit shank with zoomorphic ends. The most common endings are decorated with realistic sculptural images of the heads of birds of prey / griffins, wolves and horses. Combinations of the heads of a predatory animal and a bird of prey, a predatory animal and a horse, a camel and a horse, as well as the head of a bird of prey and a hoof are rare images. The late group refers to the period of the end of the V-IV centuries BC. This group is characterized by the following cheek-pieces: S-shaped with endings shaped as horse hooves; L-shaped with curved endings shaped as a horse's hoof or an open-work plate, which is a stylized image of a bird's paw, the claws of which are transformed into the heads of birds or animals. A significant difference between these two groups is stated and based on their composition, motives (plots) of images and their stylistics. The mapping of the findings allowed to record the concentration of the most numerous groups of cheek-pieces (straight lines with endings in the form of the heads of birds of prey / griffins, wolves, horses, and S-shaped bit shanks with endings in the form of horse hooves) on the territory of the steppes, adjoining the western slopes of the Ural Mountains. These are mainly steppes in the basin of the middle and lower reaches of the river Ilek.

Key words: Early Iron Age, Samara-Ural region, nomads, Scythian time, horse equipment, bit shanks, zoomorphic images, chronology, localization.

Citation. Myshkin V.N., 2020. Psalii s zoomorfnymi izobrazheniyami u kochevnikov Samaro-Ural'skogo regiona v VI-IV vv. do n.e. [Cheek-Pieces with Zoomorphic Images of the Samara-Ural Region Nomads in the VI-IV Centuries BC]. Nizhnevolzhskiy Arkheologicheskiy Vestnik [The Lower Volga Archaeological Bulletin], vol. 19, no. 2, pp. 56-73. DOI: https://doi.org/10.15688/nav.jvolsu.2020.2.3
\end{abstract}

УДК 903'1І634I

ББК $63.442 .14(2)-413$

Дата поступления статьи: 25.07.2020

Дата принятия статьи: 24.11.2020

\section{ПСАЛИИ С ЗООМОРФНЫМИ ИЗОБРАЖЕНИЯМИ У КОЧЕВНИКОВ САМАРО-УРАЛЬСКОГО РЕГИОНА В VI-IV вв. до Н.э. ${ }^{1}$}

\section{Владимир Николаевич Мышкин}

Самарский государственный социально-педагогический университет, г. Самара, Российская Федерация

\footnotetext{
Аннотация. Статья посвящена исследованию псалиев с зооморфными изображениями, использовавшихся кочевниками Самаро-Уральского региона в конце VI - IV в. до н.э. Представлен обзор 79 псалиев, 그 приведена их характеристика. Вся совокупность этих принадлежностей конской амуниции разделена на две خิ хронологические группы. Дата ранней группы приходится на конец VI - V в. до н.э. Для нее характерны стержневидные прямые и дуговидно изогнутые бронзовые, железные, биметаллические двудырчатые псалии с зооморфными окончаниями. Наиболее распространены окончания, украшенные реалистично выполненными скульптурными изображениями голов хищной птицы / грифона, волков и лошадей. Редкими встречаются сочетания изображений голов хищного животного и хищной птицы, хищного животного и коня, верблюда и коня, а также головы хищной птицы и копыта. Дата поздней группы - конец V - IV в. до н.э. Для

() поздней группы характерны псалии: S-видные с окончаниями в виде конских копыт; Г-образные, у одного
} 
загнутое окончание оформлено в виде копыта коня или ажурной пластины, представляющей собой стилизованное изображение лапы птицы, когти которой трансформированы в головы птиц или зверей. Констатируется значительное различие этих групп, выражающееся в их составе, мотивах (сюжетах) изображений и их стилистике. Картографирование находок позволило зафиксировать концентрацию наиболее многочисленных групп псалиев (прямых с окончаниями в виде голов хищных птиц / грифонов, волков, лошадей, а также S-видных псалиев с окончаниями в виде конских копыт) на территории степей, прилегающих к западным склонам Уральских гор. Это в основном степи в бассейне среднего и нижнего течения р. Илек.

Ключевые слова: ранний железный век, Самаро-Уральский регион, кочевники, скифское время, конское снаряжение, псалии, зооморфные изображения, хронология, локализация.

Цитирование. Мышкин В. Н., 2020. Псалии с зооморфными изображениями у кочевников СамароУральского региона в VI-IV вв. до н.э. // Нижневолжский археологический вестник. T. 19, № 2. С. 56-73. DOI: https://doi.org/10.15688/nav.jvolsu.2020.2.3

\section{Введение}

Псалии, украшенные зооморфными изображениями, являются характерной деталью конской амуниции у кочевников СамароУральского региона. Мотивы и стилистика изображений отражают специфику культурных традиций кочевого населения и их трансформаций, а также направление и характер связей с окружающими культурами. Поэтому псалии являются объектом постоянного внимания специалистов, исследовавших различные аспекты их появления и бытования у скотоводческих сообществ, населявших южноуральские степи.

В 1961 г. К.Ф. Смирнов опубликовал типологию псалиев из кочевнических курганов VI-IV вв., раскопанных в Поволжье и Южном Приуралье. В типологическую схему автором были включены и экземпляры с зооморфным оформлением. Это два Г-образных псалия из кургана 2 Мечетсайского могильника, отнесенные к третьему варианту типа I, три S-видных псалия из Акбулакского кургана, которые заканчиваются плоскими расширениями, имитирующими, вероятно, конские копыта и рассматриваемые как особый вариант типа II, один C-видный псалий из кургана 8 урочища Бис-Оба у пос. Благословенский варианта 2 типа III. Пять прямых стержневых псалиев с окончаниями в виде головок животных (лошадей) из курганов 3 и 5 у пос. Матвеевский, кургана 3 группы Алебастрова гора у пос. Нежинский, а также грифонов из кургана у хут. Черниговского выделены исследователем в тип V. Еще один костяной прямой стержневидный псалий, случайно найденный у с. Абрамовка Оренбургской области, предположительно был связан с ранними кочевниками Южного Приуралья и отнесен к типу VI [Смирнов, 1961, с. 84-87]. Таким образом, в распоряжении К.Ф. Смирнова на период разработки типологии имелось 12 псалиев с зооморфными оформлениями. Постепенное увеличение числа находок этой категории привело к появлению модифицированной типологии псалиев, бытовавших у кочевников, в том числе населявших Южное Приуралье в скифское время [Берлизов, 2011, c. 102-104].

Кроме того, псалии с зооморфным оформлением входят в число предметов, которые использовались для выделения периодов в развитии культуры кочевников Южного Приуралья. Так, особенностью хронологического периода, приходящегося на вторую половину VI $\mathrm{V}$ в. до н.э., являются уздечные наборы, в которые входили стержневидные двудырчатые псалии с зооморфными окончаниями, и прежде всего - в виде головок хищных птиц [Таиров, 2004 , с. 3 , рис. 6 ; Очир-Горяева, 2012, ил. 285 , c. 263,271$]$. Следующий прохоровский период, датированный концом V - IV в. до н.э. [Таиров, 2004, с. 3, рис. 4-11; Берлизов, 2011, с. 186-187; Очир-Горяева, 2012, с. 271], по мнению исследователей, характеризуют псалии стержневидные прямые, стержневидные с зооморфными окончаниями в виде головы лошади или хищника, а также Г-образные с окончаниями в виде зооморфных ажурных пластин [Таиров, 2004, рис. 6; Васильев, 2004, с. 153-158, 169; ОчирГоряева, 2012, с. 263, 269-271, ил. 285].

Так, в число предметов, характерных для периода, приходящегося на вторую половину VI - третью четверть V в. до н.э., включены прямые и изогнутые (C- и S-видные) псалии с 
зооморфными окончаниями [Таиров, 2004, рис. 6 ; 2009, с. 144; Берлизов, 2011, с. 183-184; Очир-Горяева, 2012, с. 259-271]. Раннепрохоровский период, временные рамки которого располагаются в пределах последней четверти V - IV в. до н.э. [Таиров, 2004, рис. 6; 2009, c. 144; Берлизов, 2011, с. 187; Очир-Горяева, 2012, с. 271], характеризуют псалии: прямые стержневидные с окончаниями в виде головы лошади или хищника, прямые с окончаниями в виде ажурных пластин [Таиров, 2004, рис. 6; Васильев, 2004, с. 153-158; Очир-Горяева, 2012, c. 269-270].

Значительное увеличение количества таких предметов конской сбруи в результате раскопок, осуществлявшихся на протяжении последних двух десятилетий, делает возможным и необходимым вновь обратиться к исследованию этой категории находок.

Цель данной статьи - представить максимально полный обзор псалиев с зооморфным оформлением из кочевнических курганов VI-IV вв. до н.э., исследованных на территории Самаро-Уральского региона и опубликованных к настоящему времени (дата наиболее поздней публикации - 2017 г.). Кроме того, предполагается изложить результаты исследования состава и характеристик этих предметов в различные периоды истории кочевников, особенности их пространственной локализации в пределах Самаро-Уральского региона.

В зависимости от формы стержня в профильной (боковой) проекции стержневидные двудырчатые псалии распределены по трем группам, которые можно обозначить как Г-образные, S- и С-видные. Всего учтено 76 псалиев и 5 зооморфных окончаний этих предметов.

\section{Обзор находок псалиев с зооморфным оформлением}

\section{Г-образные псалии}

1. Псалии (рис. 1,1 ) в виде прямого стержня, одно из окончаний которого загнуто, изгиб плавный, окончания украшены зооморфными изображениями. По предположению К.Ф. Смирнова, нижние окончания представляют собой конские копыта, верхние - головы какого-то животного. Два таких экземпля- ра обнаружены в погребении 2 кургана 2 могильника Мечет-Сай. Погребение датировано концом VI - началом V в. до н.э. [Смирнов, 1961, с. 84 , рис. 45,5$]$.

2. Псалии (рис. 1,2-3) литые бронзовые в виде прямого стержня, одно из окончаний которого резко загнуто и украшено изображением копыта коня. Второе окончание у двух псалиев отрублено в древности. Один псалий найден в паре с S-видным, поэтому не исключено, что одно из его окончаний также было отрублено. Поверхность окончаний двух экземпляров покрыта ромбическими выемками, стержень третьего украшают валики. Учтено три таких псалия. Они представлены в наборах конского снаряжения из жертвенного комплекса 1 в кургане 4 и погребения 3 кургана 16 могильника Филипповка I [Яблонский, 2013, с. 67, 175, № 35, 21432146]. Курганы датированы временем в пределах между рубежом V-IV вв. до н.э. и третьей четвертью IV в. до н.э. [Трейстер, Яблонский, 2012, с. 284].

3. Псалии (рис. 1,4-5) в виде прямого стержня, одно из окончаний которого загнуто и представляет собой ажурную пластину. Пластина располагается под углом к продольной оси стержня и плоскостью развернута перпендикулярно ей. Пластины оформлены в виде зооморфной пальметки - стилизованной лапы птицы, когти которой трансформированы: в одном случае в головы птиц, в другом - в шеи и головы зверей [Канторович, Яблонский, 2009, c. 81]. Четыре таких псалия найдены в поле кургана 3 могильника Филипповка I. Курган датирован началом IV в. до н.э. [Пшеничнюк, 2012 , с. 32,87 , рис. $56,4-5]$. Предложена также дата, не исключающая середину - вторую половину IV в. до н.э. [Канторович, Яблонский, 2009, с. 84].

4. Бронзовый стержневидный двудырчатый псалий (рис. 1,6), одно окончание которого выполнено в виде плоской пластины, расположенной под прямым углом к стержню, второе - в виде скульптурного изображения головы животного, лошади - как полагал А.Х. Пшеничнюк [Пшеничнюк, 1995, с. 81, рис. 11,14]. М.А. Очир-Горяева рассматривает это изображение как голову лося [ОчирГоряева, 2012, с. 289]. Псалий найден в скоплении принадлежностей конской амуниции на 
уровне древней поверхности в кургане 10 могильника Переволочан I [Пшеничнюк, 1995, с. 81 , рис. 11,14$]$.

\section{S-видные псалии}

1. Железный псалий, найденный в кургане 15 могильника Филипповка I [Балахванцев, Яблонский, 2007, рис. 6,7], имеет вид стержня, окончания которого слабо изогнуты в противоположные стороны. Длина отогнутых окончаний незначительная, они имеют утолщения, которые, возможно, представляют собой корродированные зооморфные изображения (рис. 1,7). Курган датирован временем в пределах между рубежом V-IV вв. до н.э. и третьей четвертью IV в. до н.э. [Трейстер, Яблонский, 2012, с. 284].

2. Металлические двудырчатые псалии, окончания которых резко (в месте изгиба стержня псалия образуется угол около $45^{\circ}$ ) загнуты в противоположные стороны. Длина загнутых окончаний равна или иногда больше длины стрежня псалия от места изгиба до его центральной части. На некоторых экземплярах имеются кольцевые валикообразные утолщения, распределенные по всему стержню либо только в пределах наконечников. Окончания украшены зооморфными изображениями, которые чаще всего интерпретируются исследователями как конские копыта.

В виде таких изображений оформлены бронзовые наконечники, надетые на окончания некоторых экземпляров, изготовленных из железа (рис. 1,8-12). По предположению А.Х. Пшеничнюка, по крайней мере на некоторых экземплярах это могло быть изображение конских фаллосов [Пшеничнюк, 2012, c. 40]. Учтено восемь таких псалиев. Три из них найдены в кургане начала IV в. до н.э. у хут. Веселый I близ с. Ак-Булак [Смирнов, 1961, рис. 47,5; 1964, с. 58]. Еще несколько находок сделаны при исследовании могильника Филипповка I. Два псалия (рис. 1,11-12) входили в состав жертвенного комплекса 1 в кургане 2 этого могильника [Яблонский, 2013, c. 61, № 14-15], один экземпляр происходит из жертвенного комплекса 1 в кургане 4 [Яблонский, 2013, с. 67, № 34], еще два (рис. 1,8,10) обнаружены в погребении кургана 6 [Пшеничнюк, 2012, рис. 86,1]. Эти комплексы датиро- ваны временем между рубежом V-IV вв. до н.э. и третьей четвертью IV в. до н.э. [Трейстер, Яблонский, 2012, с. 284; Пшеничнюк, 2012, c. 87].

\section{С-видные псалии}

1. Металлические двудырчатые псалии, стержни которых дуговидно изогнуты в одну сторону, а на обоих окончаниях имеются зооморфные изображения. К их числу можно отнести 4 псалия, три из которых (рис. 1,13-15) обнаружены в кургане 6 могильника Таксай I, датированном концом VI - началом V в. до н.э. [Лукпанова, 2014, с. 156, рис. 3,2; 6,2-3]. Еще один, вероятно, такой псалий ${ }^{2}$ (рис. 1,16 ) происходит из кургана второй половины VI в. до н.э., раскопанного у с. Варна [Таиров, Боталов, 1988 , с. 107 , рис. 5,8$]$.

2. Металлические двудырчатые псалии, стержни которых дуговидно изогнуты в одну сторону, а на одном из окончаний имеется зооморфное изображение. В рассматриваемой выборке такие псалии представлены двумя находками (рис. 1,17-18). Одна из них происходит из кургана 8 могильника Бис-Оба у пос. Благословенского. К.Ф. Смирнов полагал, что одно окончание этого псалия украшено изображением морды лошади, а второе, уплощенное, оформлено в виде копыта коня. Курган датирован V в. до н.э. [Смирнов, 1961, с. 85, рис. 48,$2 ; 1964$, с. 59$]$. Если трактовка изображения на одном окончании как головы животного (но не обязательно лошади) не вызывает возражений, то с наличием какого-то изображения, в том числе конского копыта, на втором - сложно согласиться, так как предполагаемое изображение в рельефе никак не выражено. Второй такой псалий (рис. 1,17) найден в кургане у с. Варна, отнесенном ко второй половине VI в. до н.э. [Таиров, Боталов, 1988, с. 107 , рис. 5,9$]$.

\section{Прямые стержневидные псалии}

1. Костяной двудырчатый псалий в виде слегка изогнутого стержня, одно из окончаний которого украшено резным стилизованным изображением головы животного (рис. 1,19 ), случайно найден у с. Абрамовка Оренбургской губернии. Находка датирована второй поло- 
виной VI в. до н.э. [Смирнов, 1961, с. 87, рис. 48,8-9; Смирнов, Петренко, 1963, с. 15, табл. 16,26$]$.

2. Металлические двудырчатые псалии (9 экз.), окончания которых украшены скульптурными изображениями головы коня. Головы коней повернуты в одну сторону и расположены под углом $\left(45-90^{\circ}\right)$ к продольной оси псалия (рис. 2,1-9). Они входили в состав уздечных наборов в курганах 3 и 5 группы у пос. Матвеевский (рис. 2,6-7). Эти памятники датированы соответственно IV в. до н.э. и началом V в. до н.э. [Смирнов, 1961, с. 86, рис. 48,$6 ; 1964$, рис. 34,46 ; Смирнов, Петренко, 1963, с. 16]. Два экземпляра (рис. 2,1-2) найдены в кургане 3 группы Алебастрова гора у пос. Нежинский, отнесенном к рубежу V-IV вв. до н.э. [Смирнов, 1964, с. 59-60, рис. 40,1 в]. Такие же псалии (рис. 2,3-5) обнаружены в кургане 16 могильника Кырык-Оба II, курганах 1 и 5 могильника Илекшар I, датированных первой половиной Vв. до н.э. [Гуцалов, 2007, с. 89, рис. $12, I I, 1,16, I I I, 3 ; 2009$ a, с. 75 , рис. 3,7$]$. Еще два экземпляра (рис. 2,8-9) происходят из погребения коня в кургане 9 могильника Лебедевка II. Время сооружения данного памятника приходится, по мнению автора публикации, на период с конца VI в. до н.э. до середины V в. до н.э. [Гуцалов, 2009б, с. 311-312, рис. 7,5].

3. Металлические псалии в виде прямых или слегка изогнутых стержней, окончания которых украшены скульптурными изображениями головы волка. Изображения волчьих голов продольной осью расположены по продольной оси псалия. К их числу уверенно можно отнести один бронзовый экземпляр (рис. 2,10) из кургана 15 могильника КырыкОба II. Вероятно, такую же форму имели пять биметаллических псалиев (рис. 2,11-15) из этого же кургана, имевших железные стержни и бронзовые окончания [Гуцалов, 2010, рис. 3,5-6,10-11,14-15], и два (рис. 1,16-17) из кургана 6 могильника Пятимары I [Смирнов, 1964, с. 51, рис. 29,4a]. Курган 15 могильника Кырык-Оба II датирован временем в пределах конца VI - середины V в. до н.э. [Гуцалов, 2010, с. 64], курган 6 могильника Пятимары I- началом V в. до н.э. [Смирнов, 1975, c. 22,28$]$.

4. Металлические псалии в виде прямых или слегка изогнутых стержней, окончания которых украшены скульптурными изображениями голов хищных птиц или грифонов (рис. 3,1-21). Всего учтено 27 экземпляров. Такие псалии обнаружены в погребении 1 кургана 1 могильника Акоба II [Моргунова, Краева, 2012, с. 166-167, рис. 9,5], кургане 5 Аландского III могильника [Мошкова, 1972, с. 61, рис. 5,4], погребении 3 кургана 1 могильника Березки I [Мышкин и др., 2000, с. 72; Мышкин, 2014, с. 308], кургане 4 могильника Бесоба [Кадырбаев, 1984, рис. 1,23; Кузнецова, Курманкулов, 1993, с. 48, рис. 4,9], на межкурганном пространстве могильника Кичигино I [Таиров, Ульянов, 2010 , с. 210 , рис. 1,4-5], в курганах 12, 15, 16, 17 могильника КырыкОба II [Гуцалов, 2011, с. 84-90, рис. 3,1-2,6$7,5,2,7,1,4,8,10]$, кургане 3 могильника Маровый Шлях, кургане 1 могильника Солончанка II [Таиров, 2006, с. 84, рис. 5,2, 8,3], погребении 1 кургана 4 могильника Сара [Федоров, Васильев, 2017, с. 54, рис. 3,1], кургане 6 могильника Таксай I [Лукпанова, 2014, рис. 5,3$4,7,2,8,2-3]$. По аналогии с вышеперечисленными находками можно предположить, что обломок псалия из кургана у хут. Черниговского, раскопанного в 1888 г., имел два отверстия, а не три, как полагал К.Ф. Смирнов [Смирнов, 1961 , с. 86,88 , рис. 49,4$]$. Судя по предложенным в публикациях датам, время использования кочевниками Самаро-Уральского региона псалиев с окончаниями в виде голов хищных птиц (грифонов) приходится на конец VI - V в. до н.э. и преимущественно на конец VI - первую половину V в. до н.э. [Мышкин, 2014, с. 312].

5. Металлические двудырчатые псалии в виде прямых стержней, выполненных в виде двух голов хищных птиц, обращенных клювами в разные стороны. Утолщения вокруг отверстий псалиев оформлены как собственно головы птиц (кружочками переданы глаза), а стержни, начиная от отверстий, как клювы (рис. 3,22-23). Два таких бронзовых псалия обнаружены в слое погребенной почвы кургана 3 могильника Переволочан II. Предварительно они датированы V в. до н.э. [Сиротин, 2015, с. 247, 251, рис. 1,2].

6. Металлические двудырчатые псалии, одно окончание которых представляет собой скульптурное изображение головы хищного животного, второе - головы хищной птицы / 
грифона. Изображения расположены под углом к продольной оси стержня псалия (рис. 4,1-2). Псалии найдены в поле кургана 12 могильника Кырык-Оба II, датированного концом VI - первой половиной V в. до н.э. [Гуцалов, 2011, с. 84, 93, рис. 3,1-2].

7. Металлический двудырчатый псалий, одно окончание которого оформлено в виде головы хищного животного, второе - головы лошади (рис. 4,3$)$. Этот псалий найден в кургане 5 могильника Илекшар I, отнесенном к первой половине V в. до н.э. [Гуцалов, 2007, с. 86,89 , рис. $16, I I I, 2]$.

8. Металлические двудырчатые псалии (4 экз.), одно окончание которых представляет собой скульптурное изображение головы лошади, другое - головы верблюда. Изображения расположены под углом к продольной оси стержня. Учтенные псалии отлиты из бронзы (рис. 4,4-6). Они обнаружены в кургане 3 могильника Бесоба (рис. 4,4-5), датированном концом VI - V в. до н.э. [Мамедов, 2011 , с. $200-203$, рис. $2,5-6]$, и в кургане 1 могильника Илекшар I (рис. 4,6), дата которого, по мнению С.Ю. Гуцалова, приходится на конец VI - первую половину V в. до н.э. [Гуцалов, 2009a, с. 75, рис. 3,6].

9. Металлический двудырчатый псалий, на одном окончании которого помещено изображение головы хищной птицы, а на другом изображение копыта (рис. 4,7), обнаружен в кургане 1 могильника Солончанка II, датированном концом VI - началом V в. до н. э. [Таиров, 2006, с. 89-90, рис. 8,2].

10. Металлический (бронзовый) двудырчатый псалий в виде слегка изогнутого стержня, выполненного в форме рыбы. Одна часть от отверстия для крепления к узде до окончания оформлена как голова и передняя часть туловища рыбы с передним спинным и грудным плавниками, вторая - как задняя часть туловища и хвост с задним спинным, брюшным и хвостовым плавниками (рис. 4,8). Псалий найден в юго-восточном секторе на уровне материка в кургане 4 могильника Переволочан II. В настоящее время для Южного Приуралья это уникальная находка [Сиротин, 2015 , с. 247 , рис. 1,3$]$.

11. Металлический двудырчатый псалий в виде слегка изогнутого стержня с тремя выступами в средней части и крестовидным бронзовым ограничителем, через который продето железное кольцо. Окончания псалия украшены зооморфными изображениями: одно - протомой фантастического существа, сочетающего черты хищника, похожего на волка, но снабженного рогом и ногой, завершающейся копытом, другое - протомой травоядного животного (рис. 4,9). Псалий найден в 100 м к юго-западу от кургана 1 могильника Филипповка I [Яблонский, 2013, с. 223, № 3130]. Этот курган датирован самым началом IV в. до н.э. [Пшеничнюк, 2012, с. 87] и второй половиной $\mathrm{V}$ - первой половиной IV в. до н.э. [Трейстер и др., 2012, с. 85].

\section{Наконечники псалиев}

Следует отметить отдельные сохранившиеся детали псалиев, которые невозможно отнести к какой-либо группе или типу по причине фрагментарности этих находок.

1. В кургане 1 могильника Филипповка I были найдены железные псалии, форму которых не удалось проследить из-за плохой сохранности. От них остались только четыре окончания (рис. 4,11 ), обложенные золотой фольгой. Окончания представляли собой изображение головы грифона [Пшеничнюк, 2012, c. 71 , рис. 30,2$]$. Судя по стилистике изображений, эти псалии входили в комплекс конского снаряжения иранского происхождения [Трейстер, 2012, с. 117].

2. Еще два бронзовых фрагмента псалия (рис. 4,10 ) найдены в составе комплекса конского снаряжения при исследовании южной полы кургана 3 могильника Филипповка I. Наконечники псалия представляют собой стержни с валикообразными утолщениями. Один из них заканчивается скульптурным схематичным изображением головы хищного животного (пантеры?). Голова расположена под прямым углом к продольной оси стержня псалия [Пшеничнюк, 2012, с. 32 , рис. 57,10$]$.

\section{Хронологические группы}

В соответствии с принятыми в настоящее время датами псалии с зооморфным оформлением можно разделить на две хронологические группы. Время использования кочевниками псалиев одной (ранней) группы прихо- 
V.N. Myshkin. Cheek-Pieces with Zoomorphic Images of the Samara-Ural Region Nomads

дится на вторую половину VI - V в. до н.э., другой (поздней) - на конец V - IV в. до н.э. Следует констатировать наличие существенных различий между этими двумя группами, которые проявляются в номенклатуре характерных для каждой группы псалиев, а также мотивах и стилистике зооморфных изображений, украшавших данные предметы. Существует и некоторое сходство двух групп, которое определяется наличием в них небольшого количества однотипных псалиев с зооморфными изображениями.

Первая группа (вторая половина VI- V в. до н.э.). Ее характеризуют и отличают стержневидные металлические (бронзовые, железные, биметаллические) двудырчатые псалии с зооморфными окончаниями (рис. 1,13-16, 2,3-5,7-17, 3,1-21, 4,1-7). Стержни прямые, слегка изогнутые или дуговидно изогнутые (С-видные). Окончания украшены реалистично выполненными скульптурными изображениями голов хищной птицы / грифона (это наиболее распространенный мотив), а также волков и лошадей (рис. 2,3-5,7-17, 3,1-21). Следует отметить устойчивость традиций изготовления таких псалиев. Более редкими являются сочетания изображений голов хищного животного и хищной птицы, хищного животного и коня, верблюда и коня, а также головы хищной птицы и копыта (рис. 4,1-7). Единичными экземплярами представлены костяные и металлические псалии в виде прямого или изогнутого стержня, у которых зооморфным изображением украшено только одно окончание (рис. 1,17-19), а также Г-образные экземпляры с изображением копыта на одном окончании и, вероятно, головы животного - на другом (рис. 1,1).

Вторая группа (конец V - IV в. до н.э.) в количественном отношении значительно меньше первой (ранней). Для поздней группы характерны S-видные псалии с окончаниями в виде конских копыт (рис. 1,8-12). Эту группу отличают также Г-образные экземпляры, у которых только один, загнутый, конец оформлен в виде копыта коня (рис. 1,2-3) или ажурной пластины, представляющей собой стилизованное изображение лапы птицы, когти которой трансформированы в головы птиц или зверей (рис. 1,4-5). Эту группу отличают также единичные находки: Г-образный псалий, одно прямое окончание которого украшено изображением лося или коня (рис. 1,6), S-видный псалий со слабоизогнутым стержнем и окончаниями, украшенными, как предполагают, зооморфными изображениями (рис. 1,7); псалий в виде слегка изогнутого стержня с тремя выступами в средней части и крестовидным бронзовым ограничителем, через который продето железное кольцо, и окончаниями, одно из которых имеет вид протомы фантастического существа, сочетающего черты хищника, похожего на волка, но снабженного рогом и ногой, завершающейся копытом, а другое - протомы травоядного животного (рис. 4,9). В эту же группу входят наконечники псалия, один из которых выполнен в виде схематично переданной головы хищного животного (пантеры?), расположенной под прямым углом к стержню (рис. 4,10). В это же время, судя по предложенным датам, продолжают использоваться прямые псалии с окончаниями в виде голов лошадей (рис. 2,1-2,6). Зооморфные изображения на псалиях этой группы отличает схематичность, они зачастую плоскостные.

\section{Территориальное распределение}

Картографирование наиболее многочисленных групп псалиев с зооморфным оформлением: прямых с окончаниями в виде голов хищной птицы / грифона (27 экз.), волков (8 экз.) и лошадей (9 экз.), а также S-видных с окончаниями в виде конских копыт (8 экз.), позволило получить следующую картину их распределения в пределах Самаро-Уральского региона.

Во второй половине VI - V в. до н.э., судя по анализируемой выборке, прямые псалии с окончаниями в виде головы хищной птицы / грифона (рис. 1,1-21) встречаются по всей степной территории Южного Приуралья. Отдельные экземпляры найдены в низовьях p. Самара. При этом следует отметить концентрацию таких псалиев в степях нижнего течения р. Илек (рис. 5). Прямые псалии с окончаниями в виде скульптурных изображений голов лошадей (рис. 2,3-5,7-9) встречаются как в западных, так и в восточных районах южноприуральских степей. Однако большая часть находок сделана в курганах, раскопан- 
ных на территории, прилегающей к западным склонам Уральских гор, в низовьях Илека и в районе слияния рек Урал и Сакмара (рис. 5). Прямые псалии с окончаниями в виде скульптурных изображений голов волков рассматриваемой в статье выборки (рис. 2,10-17) найдены только в памятниках среднего и нижнего течения Илека (рис. 5).

Характерные для второй группы (конец V - IV в. до н.э.) S-видные псалии с окончаниями в виде конских копыт (рис. 1,8-12) также происходят из памятников, расположенных в степях среднего и нижнего течения Илека, то есть в западных районах южноуральских степей (рис. 5).

\section{Заключение}

1. Выборка псалиев с зооморфным оформлением, происходящих из курганов СамароУральского региона VI-IV вв. до н.э., включает в себя 79 экземпляров. Зооморфными изображениями украшены псалии всех основных форм: Г-образной, С- и S-видной, прямой стержневидной. Изображения размещены, как правило, на окончаниях псалиев. В отдельных случаях весь стержень псалия представляет собой зооморфное изображение. Основные мотивы (сюжеты): головы хищных птиц / грифонов, лошадей и волков, конские копыта (или фаллические изображения). Реже встречаются изображения голов верблюдов, пантер, птичьих лап, рыб, лосей, фантастических существ, сочетающих черты хищника и травоядного животного. Как правило, на окончаниях изображены головы одного и того же вида животных. Найдены псалии, на окончаниях которых сочетаются изображения головы хищника и хищной птицы, хищника и коня, верблюда и коня, головы хищной птицы и конского копыта.
2. Псалии с зооморфным оформлением разделяются на две хронологические группы. Дата ранней группы приходится на вторую половину VI - V в. до н.э., поздней - на конец $\mathrm{V}$ - IV в. до н.э. Можно констатировать наличие существенных различий между этими двумя группами. Они проявляются в номенклатуре псалиев, характерных для каждой группы, мотивах и стилистике изображений на этих предметах. Определенное сходство двух групп проявляется в наличии некоторого количества однотипных псалиев в обеих группах (в частности, прямых стержневидных с окончаниями в виде головы коня).

3. Картографирование показало концентрацию псалиев с окончаниями в виде голов хищной птицы / грифона, волков и лошадей, а также S-видных с окончаниями в виде конских копыт в памятниках, расположенных в бассейне среднего и нижнего течения $\mathrm{p}$. Илек, то есть на территории, прилегающей к западным склонам Уральских гор.

\section{ПРИМЕЧАНИЯ}

1 Работа выполнена при поддержке Российского научного фонда, проект № 18-18-00137 «Культурные и морфогенетические связи на контактных территориях Поволжско-Казахстанских степей в период поздней бронзы и раннего железа».

This work was supported by the Russian Science Foundation, project No. 18-18-00137 "Contacts and relationships of the population of the Ural-Volga and Kazakhstan steppes during the Late Bronze Age and Early Iron Age".

2 Псалий деформирован, и авторы публикации интерпретируют его как Г-образный [Таиров, Боталов, 1988, с. 105]. Этот псалий найден в паре с С-видным экземпляром. Поэтому более вероятной представляется именно такая первоначальная форма рассматриваемой находки. 


\section{ИЛЛЮСТРАЦИИ}
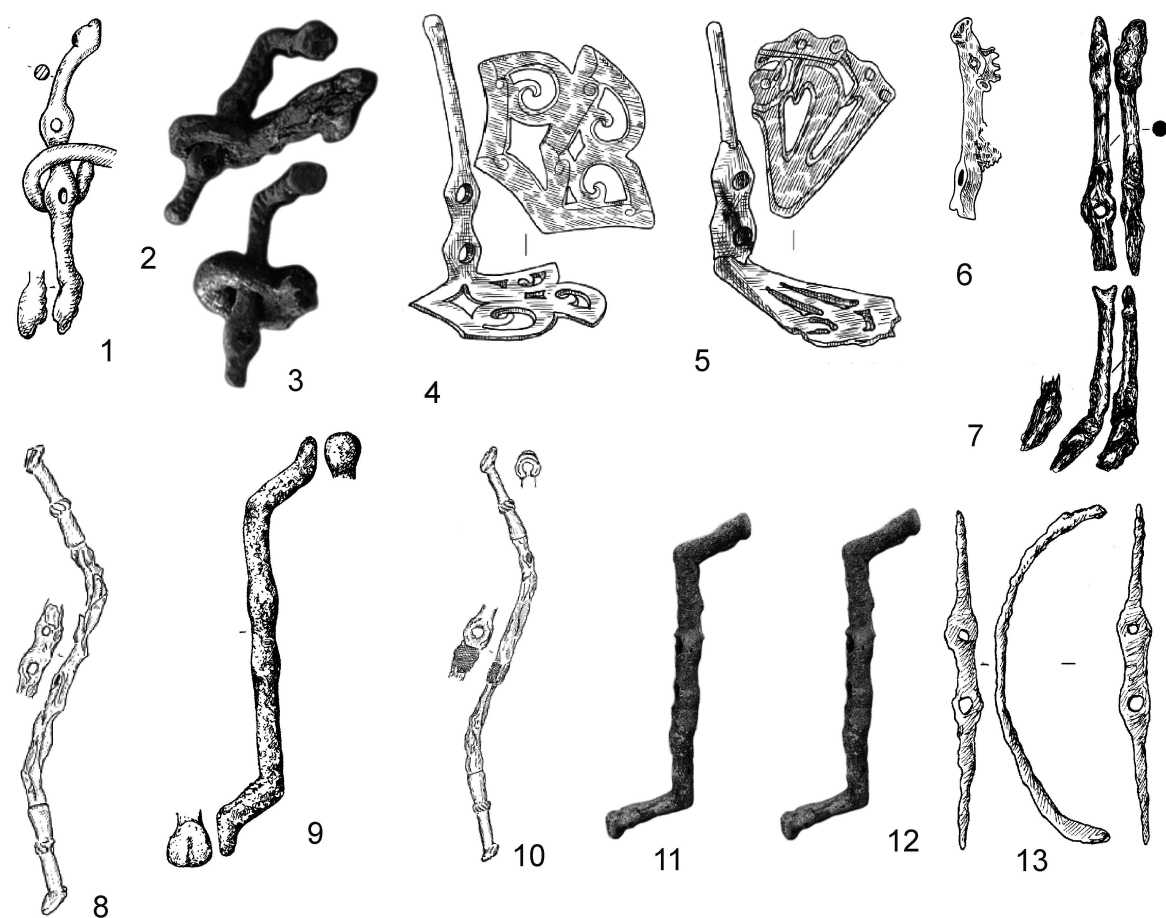

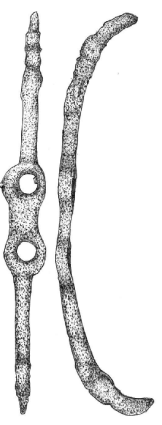

14

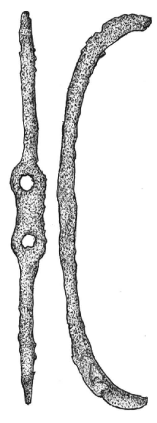

15

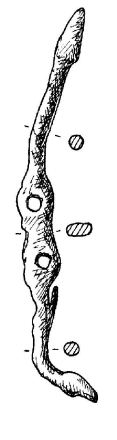

16

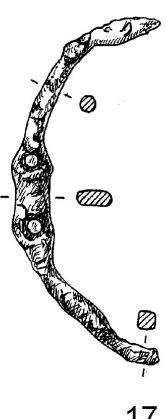

$0 \quad 5 \mathrm{~cm}$

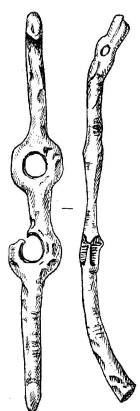

18

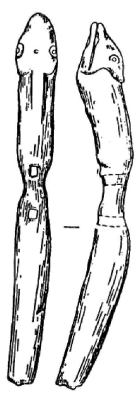

19

Рис. 1. Псалии с зооморфными окончаниями:

1 - Мечет-Сай, кург. 2, погр. 2 (по: [Смирнов, 1961, рис. 45,5]); 2-3 - Филипповка I, кург. 16, погр. 3 (по: [Яблонский, 2013, № 2143-2146]); 4-5 - Филипповка I, кург. 3 (по: [Пшеничнюк, 2012, рис. 56,4-5]); 6 - Переволочан I, кург. 10 (по: [Пшеничнюк, 1995, рис. 11,4]); 7 - Филипповка I, кург. 15, погр. 1 (по: [Балахванцев, Яблонский, 2007, рис. 6,7]); 8, 10 - Филипповка I, кург. 6 (по: [Пшеничнюк, 2012, рис. 86,2-3]); 9 - хут. Веселый I, с. Ак-Булак (по: [Смирнов, 1961, рис. 47,5-6]); 11-12 - Филипповка I, кург. 2, жертв. комплекс 1 (по: [Яблонский, 2013, № 14-15 ]); 13-15 - Таксай I, кург. 6 (по: [Лукпанова, 2014, рис. 3,2, 6,3-4]);

16-17 - кург. у с. Варна (по: [Таиров, Боталов, 1988, рис. 5,8]); 18 - Бис-Оба, пос. Благословенский, кург. 8 (по: [Смирнов, 1961, рис. 48,2]); 19 - Абрамовка, случайная находка (по: [Смирнов, 1961, рис. 48,9]). 1, 7, 9 - железо; 2-6, 11-15 - бронза; 8, 10, 16-18- железо, бронза; 19 - кость

Fig. 1. Check-pieces with zoomorphic endings:

1 - Mechet-Sai, kurgan 2, burial 2 (after: [Smirnov, 1961, fig. 45,5]); 2-3 - Filippovka I, kurgan 16, burial 3 (after: [Yablonskiy, 2013, no. 2143-2146]); 4-5 - Filippovka I, kurgan 3 (after: [Pshenichnyuk, 2012, fig. 56,4-5]); 6 - Perevolochan I, kurgan 10 (after: [Pshenichnyuk, 1995, fig. 11,4]); 7 - Filippovka I, kurgan 15, burial 1 (after: [Balakhvantsev, Yablonskiy, 2007, fig. 6,7]); 8, 10 - Filippovka I, kurgan 6 (after: [Pshenichnyuk, 2012, fig. 86,2-3]);

9 - Veselyy I (Ak-Bulak) (after: [Smirnov, 1961, fig. 47,5-6]); 11-12 - Filippovka I, kurgan 2, sacrificial complex 1 (after: [Yablonskiy, 2013, no. 14-15]); 13-15 - Taksai I, kurgan 6 (after: [Lukpanova, 2014, fig. 3,2, 6,3-4]); 16-17 - kurgan near Varna (after: [Tairov, Botalov, fig. 5,8]); 18 - Bis-Oba, Blagoslovensky, kurgan 8 (after: [Smirnov, 1961, fig. 48,2]); 19 - Abramovka, an accidental find (after: [Smirnov, 1961, fig. 48,9]).

$$
\text { 1, 7,9- iron; 2-6, 11-15- bronze; } 8,10,16-18 \text { - iron, bronze; } 19 \text { - bone }
$$




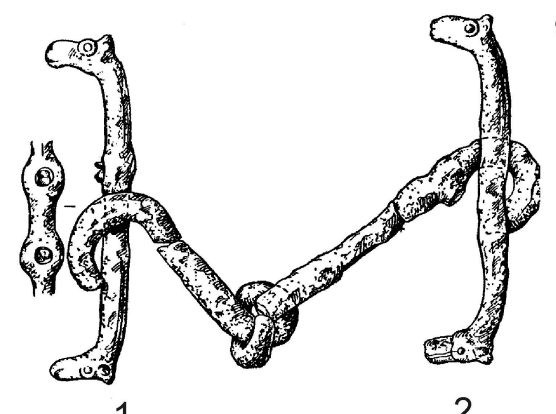

1
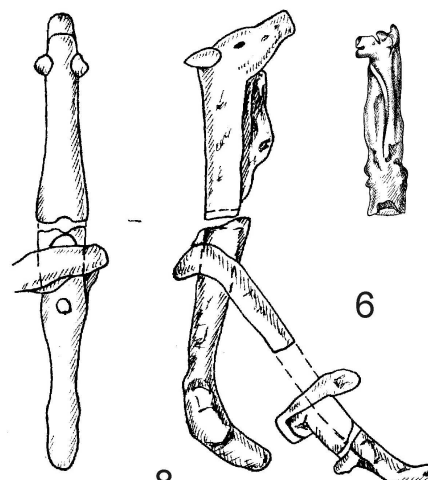

2

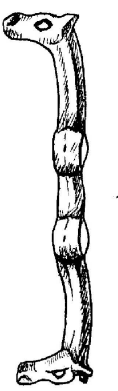

कि

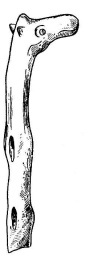

3

3
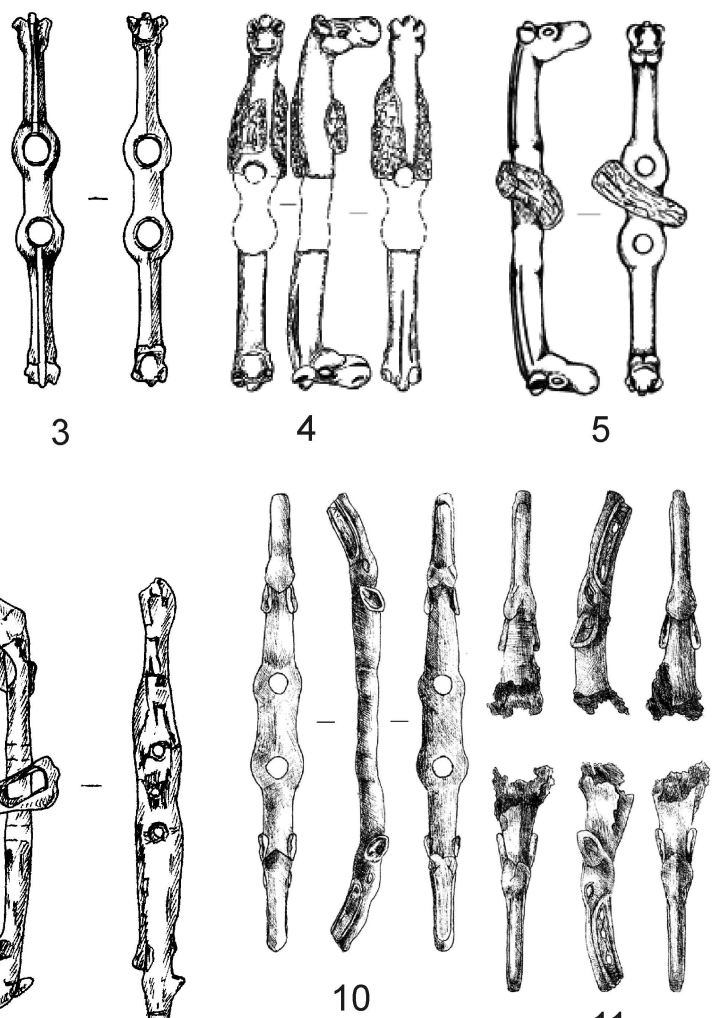

11
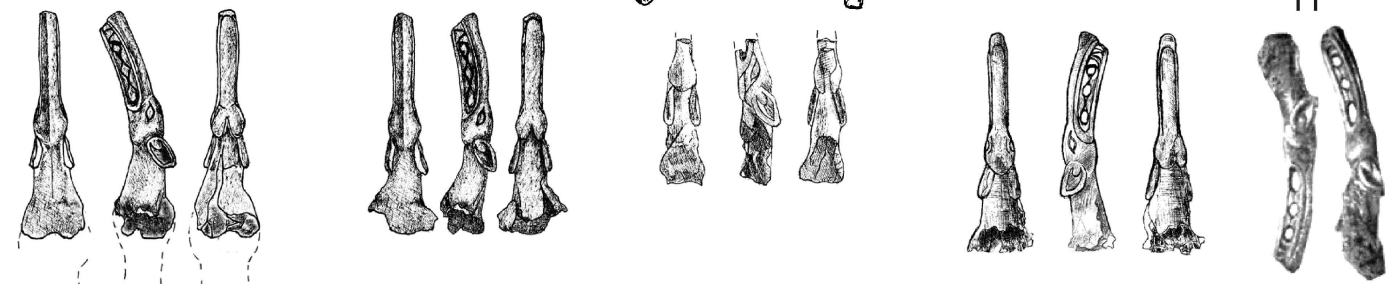

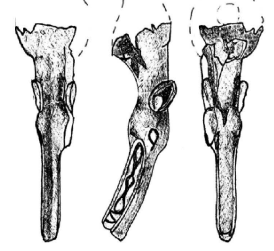

12

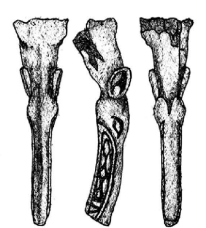

13

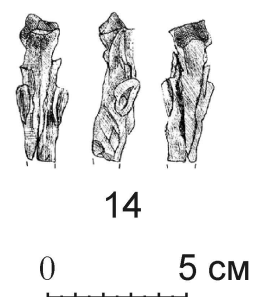

$5 \mathrm{~cm}$

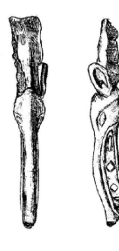

15

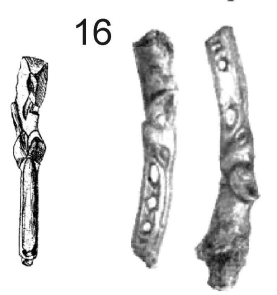

17

Рис. 2. Псалии с окончаниями в виде голов коней и волков:

1-2 - Алебастрова гора, кург. 3 (по: [Смирнов, 1961, рис. 48,7]); 3 - Кырык-Оба II, кург. 16

(по: [Гуцалов, 2007, рис. 12,II,1]); 4 - Илекшар I, кург. 1 (по: [Гуцалов, 2009а, рис. 3,7]); 5 - Илекшар I, кург. 5

(по: [Гуцалов, 2007, рис. 16,III,3]); 6 - Матвеевский, кург. 3 (по: [Смирнов, 1961, рис. 48,6]);

7 - Матвеевский, кург. 5 (по: [Смирнов, 1964, рис. 34,4б]); 8-9 - Лебедевка II, кург. 9 (по: [Гуцалов, 2009б, рис. 7,5]); 10-15 - Кырык-Оба II, кург. 15 (по: [Гуцалов, 2010, рис. 3,5-6,10-11,14-15]); 16-17 - Пятимары I, кург. 6, погр. коня (по: [Смирнов, 1964, рис. 29,4a]).

6, 8-9 - железо; $1-5,7,10-11$ - бронза, $12-17$ - бронза и железо

Fig. 2. Cheeks with endings in the form of the heads of horses and wolves:

1-2 - Alebastrova Gora, kurgan 3 (after: [Smirnov, 1961, fig. 48,7]); 3 - Kyryk-Oba II, kurgan 16

(after: [Gutsalov, 2007, fig. 12,II,1]); 4 - Ilekshar I, kurgan 1 (after: [Gutsalov, 2009a, fig. 3,7]); 5 - Ilekshar I, kurgan 5

(after: [Gutsalov, 2007, fig. 16,III,3]); 6 - Matveevsky, kurgan 3 (after: [Smirnov, 1961, fig. 48,6]);

7 - Matveevsky, kurgan 5 (after: [Smirnov, 1964, fig. 34,4b]); 8-9 - Lebedyovka II, kurgan 9 (after: [Gutsalov, 2009b, fig. 7,5]); 10-15 - Kyryk-Oba II, kurgan 15 (after: [Gutsalov, 2010, fig. 3,5-6,10-11,14-15]);

16-17 - Pyatimary I, kurgan 6, horse burial (after: [Smirnov, 1964, fig. 29,4a]). $6,8-9$ - iron; $1-5,7,10-11$ - bronze, $12-17$ - bronze and iron 


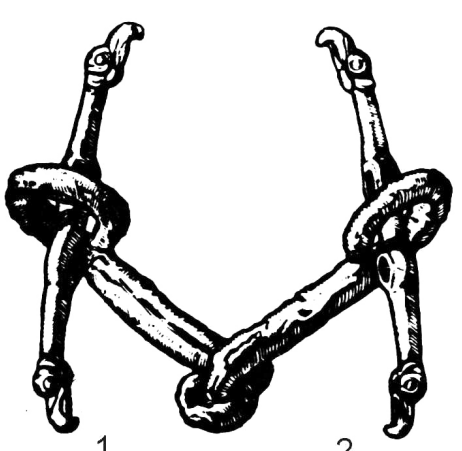

2
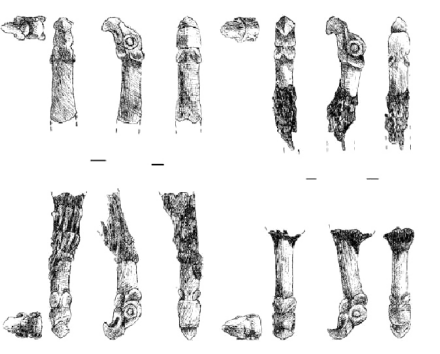

7

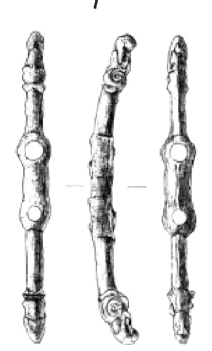

14

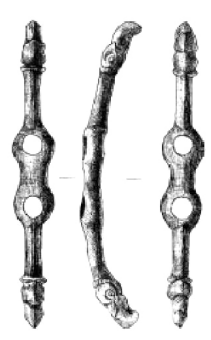

15
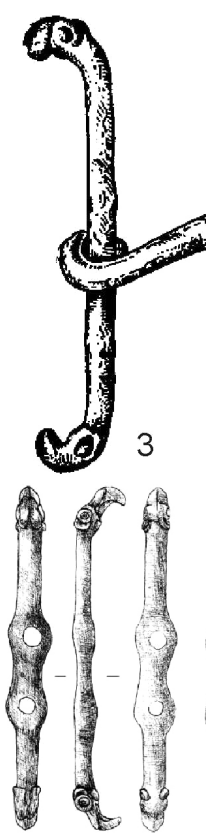

9

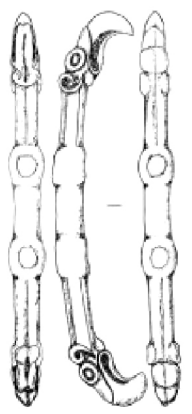

5

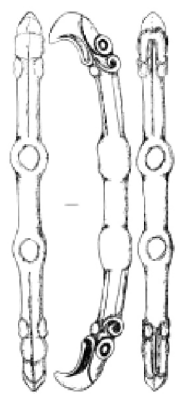

6
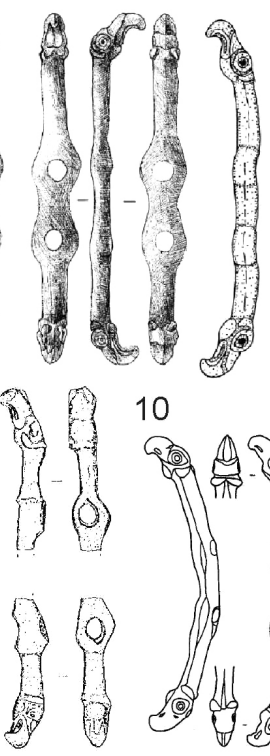

17

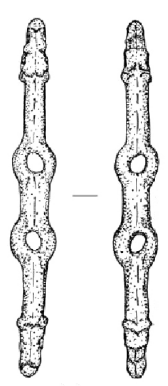

11

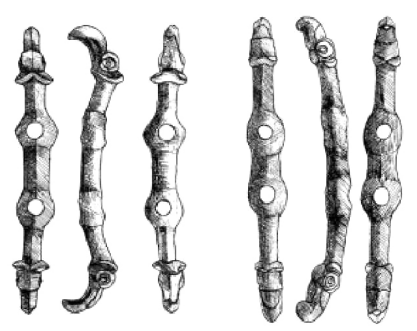

12

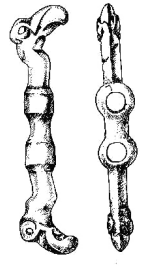

16

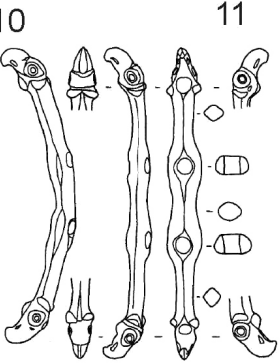

18

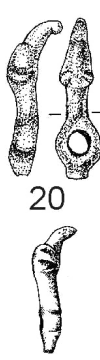

21
13

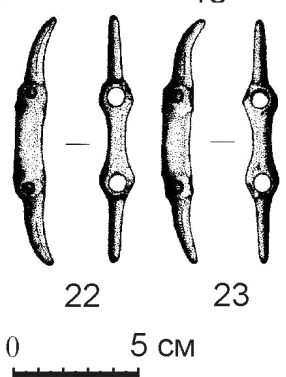

Рис. 3. Псалии с окончаниями в виде голов хищных птиц:

1-2 - Бесоба, кург. 4 (по: [Кадырбаев, 1984, рис. 1,23]); 3-4 - Аландский III, кург. 5 (по: [Мошкова, 1972, рис. 5,4]); 5-6 - Кырык-Оба II, кург. 12 (по: [Гуцалов, 2011, рис. 3,6-7]);

7-10 - Кырык-Оба II, кург. 15 (по: [Гуцалов, 2010, рис. 2,2-3; 3,I,1-2]);

11 - Кырык-Оба II, кург. 16 (по: [Гуцалов, 2011, рис. 5,2]);

12-15 - Кырык-Оба II, кург. 17 (по: [Гуцалов, 2011, рис. 7,1,4,8,10]);

16 - Маровый шлях, кург. 3 (по: [Таиров, 2006, рис. 5,2]);

17 - Солончанка II, кург. 1 (по: [Таиров, 2006, рис. 8,3]);

18-19 - Кичигино I, межкурганное пространство (по: [Таиров, Ульянов, 2010, рис. 1,4-5]);

20 - Акоба II, кург. 1, погр. 1 (по: [Моргунова, Краева, 2012, рис. 9,5]);

21 - кург. у хут. Черниговский (по: [Смирнов, 1961, рис. 49,4]);

22-23 - Переволочан II, кург. 3 (по: [Сиротин, 2015, рис. 1,2]).

$1-2,5-6,9-23$ - бронза, 3-4 - железо, 7-8 - железо и бронза

Fig. 3. Cheeks with endings in the form of heads of birds of prey:

1-2 - Besoba, kurgan 4 (after: [Kadyrbaev, 1984, fig. 1,23]); 3-4 - Alandsky III, kurgan 5 (after: [Moshkova, 1972, fig. 5,4]); 5-6 - Kyryk-Oba II II, kurgan 12 (after: [Gutsalov, 2011, fig. 3,6-7]);

7-10 - Kyryk-Oba II, kurgan 15 (after: [Gutsalov, 2010, fig. 2,2-3; 3,I,1-2]);

11 - Kyryk-Oba II, kurgan 16 (after: [Gutsalov, 2011, fig. 5,2]);

12-15 - Kyryk-Oba II, kurgan 17 (after: [Gutsalov, 2011, fig. 7,1,4,8,10]);

16 - Marovy shlyakh, kurgan 3 (after: [Tairov, 2006, fig. 5,2]);

17 - Solonchanka II, kurgan 1 (after: [Tairov, 2006, fig. 8,3]);

18-19 - Kichigino I, inter-kurgan terrytory (after: [Tairov, Ulyanov, 2010, fig. 1,4-5]);

20 - Akoba II, kurgan 1, burial 1 (after: [Morgunova, Kraeva, 2012, fig. 9,5]);

21 - kurgan at the farm of Chernigovsky (after: [Smirnov, 1961, fig. 49,4]);

22-23 - Perevolochan II, kurgan 3 (after: [Sirotin, 2015, fig. 1,2]).

$1-2,5-6,9-23$ - bronze, 3-4 - iron, 7-8 - iron and bronze 


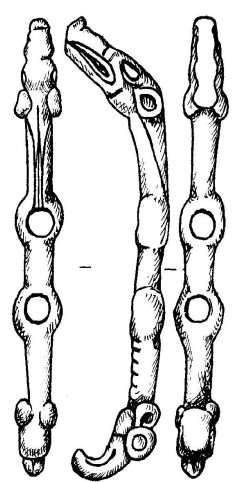

1

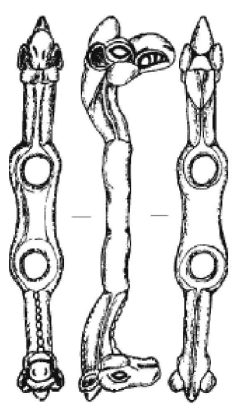

6

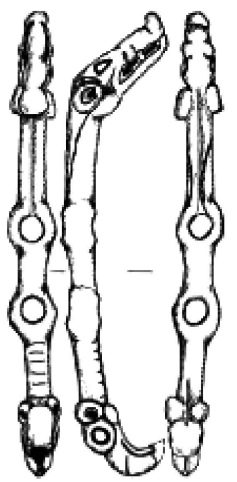

2

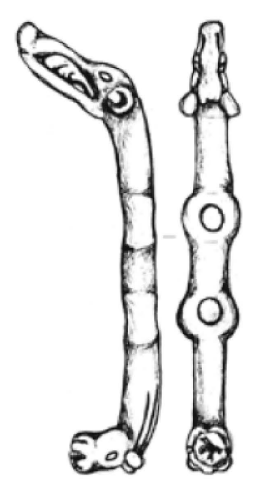

3

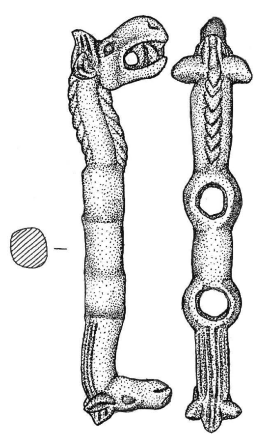

4

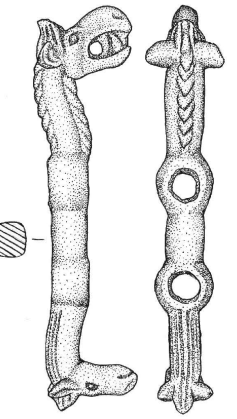

5

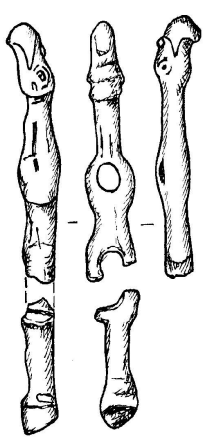

7

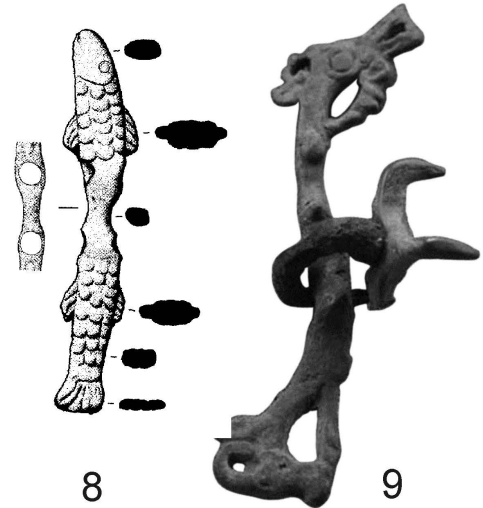

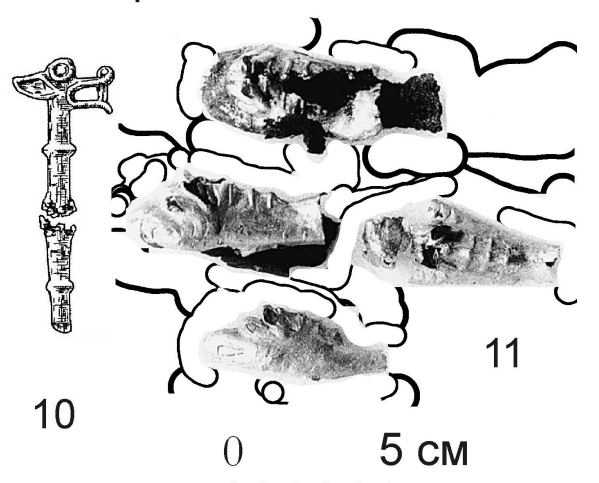

для 1, 2, 4-8, 10, 11

Рис. 4. Псалии с зооморфными окончаниями и зооморфные наконечники псалиев:

1-2 - Кырык-Оба II, кург. 12 (по: [Гуцалов, 2011, рис. 3,1-2]);

3 - Илекшар I, кург. 5 (по: [Гуцалов, 2007, рис. 16,III,2]);

4-5 - Бесоба II, кург. 3 (по: [Мамедов, 2011, рис. 2,5-6]);

6 - Илекшар I, кург. 1 (по: [Гуцалов, 2009а, рис. 3,6]);

7 - Солончанка II, кург. 1 (по: [Таиров, 2006, рис. 8,2]);

8 - Переволочан II, кург. 4 (по: [Сиротин, 2015, рис. 1,3]);

9 - Филипповка I, кург. 1, околокурганное пространство (по: [Яблонский, 2013, № 3130]);

10 - Филипповка I, кург. 3 (по: [Пшеничнюк, 2012, рис. 57,10]);

11 - Филипповка I, кург. 1 (по: [Пшеничнюк, 2012, рис. 30,2]).

$$
1-10 \text { - бронза, } 11 \text { - золото }
$$

Fig. 4. Cheekpieces with zoomorphic endings and zoomorphic cheekpiece tips:

1-2 - Kyryk-Oba II, kurgan 12 (after: [Gutsalov, 2011, fig. 3,1-2]);

3 - Ilekshar I, kurgan 5 (after: [Gutsalov, 2007, fig. 16,III,2]);

4-5 - Besoba II, kurgan 3 (after: [Mamedov, 2011, fig. 2,5-6]);

6 - Ilekshar I, kurgan 1 (after: [Gutsalov, 2009a, fig. 3,6]);

7 - Solonchanka II, kurgan 1 (after: [Tairov, 2006, fig. 8,2]);

8 - Perevolochan II, kurgan 4 (after: [Sirotin, 2015, fig. 1,3]);

9 - Filippovka I, kurgan 1, near the burial area (after: [Yablonskiy, 2013, no. 3130]);

10 - Filippovka I, kurgan 3 (after: [Pshenichnyuk, 2012, fig. 57,10]);

11 - Filippovka I, kurgan 1 (after: [Pshenichnyuk, 2012, fig. 30,2]).

$$
1-10 \text { - bronze, } 11 \text { - gold }
$$




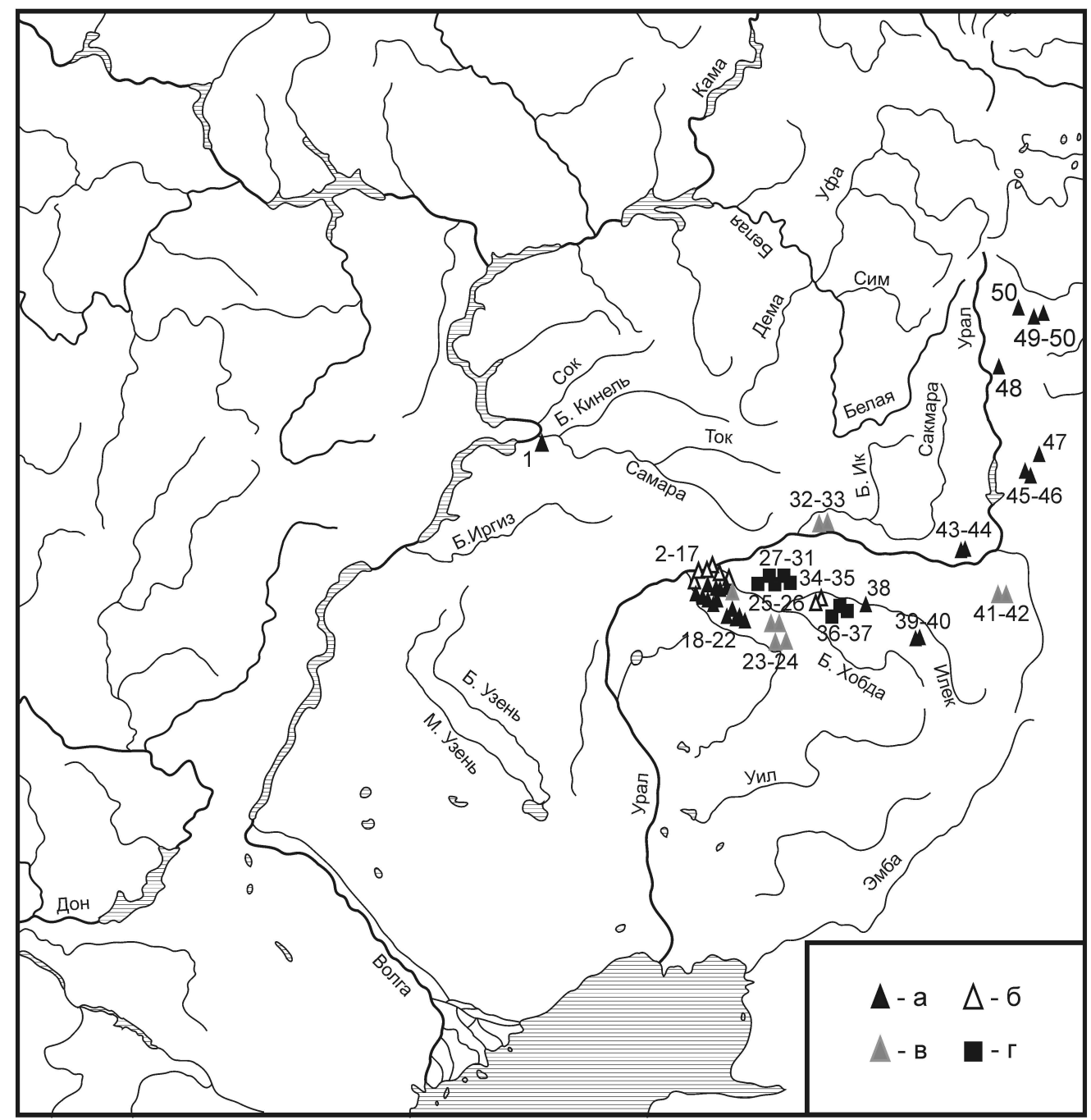

Рис. 5. Карта-схема находок прямых псалиев с окончаниями в виде голов хищной птицы / грифона, коня, волка и S-видных псалиев с окончаниями в виде конских копыт:

Условные обозначения: $a$ - прямые псалии с окончаниями в виде головы хищной птицы / грифона, $\sigma$ - прямые псалии с окончаниями в виде головы волка,

в - прямые псалии с окончаниями в виде головы коня,

2 - S-видные псалии с окончаниями в виде конского копыта.

1 - Березки I, кург. 1, погр. 3; 2-17 - Кырык-Оба II, кург. 12, 15, 16, 17; 18-20 - Таксай I, кург. 6; 23-24 - Лебедевка II, кург. 9; 25-26 - Илекшар I, кург. 1, 5; 27-31 - Филипповка I, кург. 2, 4, 6; 32-33 - Алебастрова гора, кург. 3; 34-35 - Пятимары I, кург. 6; 36-37 - Веселый I (Ак-Булак);

38 - Акоба II, кург. 1, погр. 1; 39-40 - Бесоба, кург. 4; 41-42 - Матвеевский, кург. 3, 5;

43-44 - Сара, кург. 4, погр. 1; 45-46 - Аландский III, кург. 5; 47 - Маровый шлях, кург. 3; 48 - курган у хут. Черниговский; 49-50 - Кичигино I; 51 - Солончанка II, кург. 1

Fig. 5. Schematic map of finds of straight cheek-pieces with endings in the form of a head of a bird of prey / griffin, horse, wolf and S-shaped cheek-pieces with endings in the form of horse hooves:

Legend: $a$ - straight cheekpieces with endings in the form of the head of a bird of prey / griffin, $b$ - straight cheekpieces with endings in the form of a wolf's head, $c$ - straight cheekpieces with endings in the form of a horse's head, $d$-S-shaped cheekpieces with endings in the form of a horse hooves.

1 - Berezki I, kurgan 1, burial 3; 2-17 - Kyryk-Oba II, kurgan 12, 15, 16, 17; 18-20 - Taksai I, kurgan 6; 23-24 - Lebedyovka II, kurgan 9; 25-26 - Ilekshar I, kurgan 1, 5; 27-31 - Filippovka I, kurgan 2, 4, 6; 32-33 - Mount Alabastrov, kurgan 3; 34-35 - Pyatimary I, kurgan 6; 36-37 - Veselyy I (Ak-Bulak);

38 - Akoba II, kurgan 1, burial 1; 39-40 - Besoba, kurgan 4; 41-42 - Matveevsky, kurgan 3, 5;

43-44 - Sara, kurgan 4, burial 1; 45-46 - Alandsky III, kurgan 5; 47 - Marovy shlyakh, kurgan 3; 48 - kurgan at the farm Chernigovsky; 49-50 - Kichigino I; 51 - Solonchanka II, kurgan 1 


\section{СПИСОК ЛИТЕРАТУРЫ}

Балахванцев А. С., Яблонский Л. Т., 2007. Ахеменидская эмаль из Филипповки (проблема хронологии памятника) // Российская археология. № 1. С. 143-149.

Берлизов Н. Е., 2011. Ритмы Сарматии. Савромато-сарматские племена Южной России в VII в. до н.э. V в. н.э. Ч. І. Краснодар : КГУКИ, Парабеллум. 320 с.

Васильев В. Н., 2004. К хронологии раннепрохоровского комплекса // Уфимский археологический вестник. Вып. 5. С. 153-172.

Гуцалов С. Ю., 2007. Погребальные памятники кочевой элиты Южного Приуралья середины I тыс. до н.э. // Археология, этнография и антропология Евразии. № 2. С. 75-92.

Гуцалов С. Ю., 2009а. Погребение знатного кочевника скифского времени в урочище Илекшар // Российская археология. № 3. С. 73-78.

Гуцалов С. Ю., 2009б. Погребение скифской эпохи могильников Лебедевка II-III // Нижневолжский археологический вестник. Вып. 10. С. 306-324.

Гуцалов С. Ю., 2010. Погребение сооружения могильника Кырык-Оба в Западном Казахстане // Российская археология. № 2. С. 51-66.

Гуцалов С. Ю., 2011. Этнокультурная специфика могильника Кырык-Оба II // Российская археология. № 1. C. $81-96$.

Кадырбаев М. К., 1984. Курганные некрополи верховьев Илек // Древности Евразии в скифо-сарматское время. М. : Наука. С. 84-107.

Канторович А. Р., Яблонский Л. Т., 2009. О северопричерноморских и северокавказских параллелях изображениям в скифо-сибирском зверином стиле на предметах из Филипповских курганов // Нижневолжский археологический вестник. Вып. 10. С. 73-99.

Кузнецова Э. Ф., Курманкулов Ж. К., 1993. Бронзовые изделия из памятников савроматской культуры Западного Казахстана (данные спектрального анализа) // Кочевники урало-казахстанских степей. Екатеринбург : УИФ Наука. С. 44-52.

Лукпанова Я. А., 2014. Комплекты конского снаряжения кургана № 6 комплекса Таксай 1 (предварительный обзор) // Всадники великой степи: традиции и новации. Астана : Издательская группа ФИА им. А.Х. Маргулана в г. Астана. С. 149-160.

Мамедов А. М., 2011. Новое погребение со столом-ложем на р. Илек // Сакская культура Сарыарки в контексте изучения этносоциокультурных процессов степной Евразии : тез. докл. Круглого стола, посвящ. 20-летию Независимости Республики Казахстан. Караганда. С. 199-205.

Моргунова Н. Л., Краева Л. А., 2012. Курганная группа Акоба II // Археологические памятники Оренбуржья. Вып. 10. Оренбург : Изд-во ОГПУ. С. 156-199.

Мошкова М. Г., 1972. Савроматские памятники северо-восточного Оренбуржья // Памятники Южного Приуралья и Западной Сибири сарматского времени. Материалы и исследования по археологии СССР. № 153. М. : Наука. С. 49-78.

Мышкин В. Н., 2014. Псалии с окончаниями в виде голов хищных птиц у кочевников Самаро-Уральского региона // Известия СНЦ РАН. Т. 16, № 3. С. 308-313.

Мышкин В. Н., Скарбовенко В. А., Хохлов А. А., 2000. Кочевники Самарского Поволжья во второй половине I тысячелетия до н.э. // Раннесарматская культура: формирование, развитие, хронология : материалы IV Междунар. конф. «Проблемы сарматской археологии и истории». Самара : СНЦ РАН. С. 71-84.

Очир-Горяева М. А., 2012. Древние всадники степей Евразии. М. : Таус. 472 с.

Пшеничнюк А. Х., 1995. Переволочанский могильник // Курганы кочевников Южного Урала. Уфа : Гилем. C. 62-96.

Пшеничнюк А. Х., 2012. Филипповка: Некрополь кочевой знати IV века до н.э. на Южном Урале. Уфа : ИИЯЛ УНЦРАН. 280 c.

Сиротин С. В., 2015. Предметы конской сбруи из насыпей курганов ранних кочевников Южного Урала (по материалам раскопок 2008-2013 годов) // Этнические взаимодействия на Южном Урале : материалы VI Bсерос. науч. конф. Челябинск : ОГБУК Челябинский государственный краеведческий музей. C. 247-255. 
V.N. Myshkin. Cheek-Pieces with Zoomorphic Images of the Samara-Ural Region Nomads

Смирнов К. Ф., 1961. Вооружение савроматов. Материалы и исследования по археологии СССР. № 101. М. : AHCCCP. $170 \mathrm{c}$.

Смирнов К. Ф., 1964. Савроматы. Ранняя история и культура сарматов. М. : Наука. 380 с.

Смирнов К. Ф., 1975. Сарматы на Илеке. М. : Наука. 176 с.

Смирнов К. Ф., Петренко В. Г., 1963. Савроматы Поволжья и Южного Приуралья. Свод археологических источников. Вып. Д1-9. М. : АНСССР. 40 с.

Таиров А. Д., 2004. Периодизация памятников ранних кочевников Южного Зауралья 7-2 вв. до н.э. // Сарматские культуры Евразии : проблемы региональной хронологии : докл. к 5-й Междунар. конф. «Проблемы сарматской археологии и истории». Краснодар. С. 3-21.

Таиров А. Д., 2006. Саки Приаралья в степях Южного Зауралья (по материалам могильника Маровый шлях) // Южный Урал и сопредельные территории в скифо-сарматское время : сб. ст. к 70-летию Анатолия Харитоновича Пшеничнюка. Уфа : Гилем. С. 76-91.

Таиров А. Д., 2009. О трансформации культуры кочевников Южного Урала в конце V - начале IV вв. до н.э. // Нижневолжский археологический вестник. Вып. 10. С. 137-148.

Таиров А. Д., Боталов С. Г., 1988. Курган у с. Варна // Проблемы археологии Урало-Казахстанских степей. Челябинск : Изд-во Башкир. гос. ун-та. С. 100-125.

Таиров А. Д., Ульянов И. В., 2010. Случайные находки предметов раннего железного века на Южном Урале // Гороховские чтения : материалы первой региональной музейной конференции. Челябинск : ОГБУК Челябинский государственный краеведческий музей. С. 210-216.

Трейстер М. Ю., 2012. Предметы вооружения и конского снаряжения ахеменидского круга из Южного Приуралья // Влияния ахеменидской культуры в Южном Приуралье (V-III вв. до н.э.). Т. І. М. : Таус. C. $115-116$.

Трейстер М. Ю., Яблонский Л. Т., 2012. К вопросу об абсолютной дате могильника Филипповка-І // Влияния ахеменидской культуры в Южном Приуралье (V-III вв. до н.э.). Т. І. М. : Таус. С. 282-284.

Трейстер М. Ю., Шемаханская М. С., Яблонский Л. Т., 2012. Комплексы с предметами ахеменидского круга могильника Покровка // Влияния ахеменидской культуры в Южном Приуралье (V-III вв. до н.э.). Т. II. M. : Tayc. C. $85-156$.

Федоров В. К., Васильев В. Н., 2017. Уздечный набор с бляхами в виде рыб из кургана № 4 могильника Сара в восточном Оренбуржье // Вестник ЮУрГУ. Серия «Социально-гуманитарные науки». Т. 17, № 1. С. 54-62. DOI: $10.14529 /$ ssh170109

Яблонский Л. Т., 2013. Золото сарматских вождей. Элитный некрополь Флипповка I (по материалам раскопок 2004-2009 гг.). Каталог коллекции. Кн. 1. М. : Изд-во ИА РАН. 232 с.

\section{REFERENCES}

Balahvancev A.S., Yablonskiy L.T., 2007. Ahemenidskaya emal' iz Filippovki (problema hronologii pamyatnika) [Achaemenid Enamel from Filippovka and the Chronology of the Monument)]. Rossiyskaya arkheologiya [Russian Archaeology], no. 1, pp. 143-149.

Berlizov N.E., 2011. Ritmy Sarmatii. Savromato-sarmatskie plemena Yuzhnoy Rossii v VII v. do n.e. - V v. n.e. [Rhythms of Sarmatia. Sauromat-Sarmatian Tribes of Southern Russia in the $7^{\text {th }}$ Century BC - V Century AD]. P. I. Krasnodar, KSUCA, Parabellum Publ. 320 p.

Vasiliev V.N., 2004. K hronologii ranneprohorovskogo kompleksa [On the Chronology of the Early Prokhorovka Complex]. Ufimskiy arheologicheskiy vestnik [Ufa Archaeological Herald], iss. 5, pp. 153-172.

Gutsalov S.Yu., 2007. Pogrebal'nye pamyatniki kochevoy elity Yuzhnogo Priural'ya serediny I tys. do n.e. [Burial Monuments of the Nomadic Elite of the Southern Urals in the Middle of the ${ }^{1 \text { st }}$ Millennium BC]. Arheologiya, etnografiya i antropologiya Evrazii [Archaeology, Ethnography \& Anthropology of Eurasia], no. 2, pp. 75-92.

Gutsalov S.Yu., 2009a. Pogrebenie znatnogo kochevnika skifskogo vremeni v urochishche Ilekshar [Burial of a Noble Nomad at Ilekshar (South Ural), Scythian Time]. Rossiyskaya arkheologiya [Russian Archaeology], no. 3, pp. 73-78.

Gutsalov S.Yu., 2009b. Pogrebenie skifskoy epohi mogil'nikov Lebedevka II-III [Tombs of the Scythian Period of Burial Ground Lebedevka II]. Nizhnevolzhskiy Arheologicheskiy Vestnik [The Lower Volga Archaeological Bulletin], iss. 10, pp. 306-324. 
Gutsalov S.Yu., 2010. Pogrebenie sooruzheniya mogil'nika Kyryk-Oba II v Zapadnom Kazahstane [Burial Structures of Kyryk-Oba II Cemetery in Western Kazakhstan]. Rossiyskaya arkheologiya [Russian Archaeology], no. 2, pp. 51-66.

Gutsalov S.Yu., 2011. Etnokul'turnaya specifika mogil'nika Kyryk-Oba II [The Ethnic and Cultural Specifics of Kyryk-Oba II Cemetery]. Rossiyskaya arkheologiya [Russian Archaeology], no. 1, pp. 81-96.

Kadyrbaev M.K., 1984. Kurgannye nekropoli verhov'ev Ilek [Burial Necropolises of the Upper Reaches of the Ilek]. Drevnosti Evrazii v skifo-sarmatskoe vremya [Antiquities of Eurasia in the Scythian-Sarmatian Time]. Moscow, Nauka Publ., pp. 84-107.

Kantorovich A.R., Yablonskiy L.T., 2009. O severoprichernomorskih i severokavkazskih parallelyah izobrazheniyam v skifo-sibirskom zverinom stile na predmetah iz Filippovskih kurganov [North-Pontic and North-Caucasian Analogies to the Scytho-Siberian Images Decorating the Objects from the Filippovka Barrows]. Nizhnevolzhskiy Arheologicheskiy Vestnik [The Lower Volga Archaeological Bulletin], iss. 10, pp. 73-99.

Kuznetsova E.F., Kurmankulov Zh.K., 1993. Bronzovye izdeliya iz pamyatnikov savromatskoy kul'tury Zapadnogo Kazahstana (dannye spektral'nogo analiza) [Bronze Items from the Monuments of the Sauromat Culture of Western Kazakhstan (Spectral Analysis Data)]. Kochevniki uralo-kazahstanskih stepey [Nomads of the Ural-Kazakh Steppes]. Ekaterinburg, UIF Nauka Publ., pp. 44-52.

Lukpanova Ya.A., 2014. Komplekty konskogo snaryazheniya kurgana № 6 kompleksa Taksay 1 (predvaritel'nyy obzor) [Sets of Horse Equipment for Kurgan No. 6 of the Taksai 1 Complex (Preliminary Review)]. Vsadniki velikoy stepi: traditsii i novatsii [Riders of the Great Steppe: Traditions and Innovations]. Astana, Publishing group of the FIA named after A.N. Margulan in Astana, pp. 149-160.

Mamedov A.M., 2011. Novoe pogrebenie so stolom-lozhem na r. Ilek [New Burial with a Table-bed on the River Ilek]. Sakskaya kul'tura Saryarki v kontekste izucheniya etnosociokul'turnyh processov stepnoy Evrazii. Tezisy dokladov Kruglogo stola, posvyashchyonnogo 20-letiyu Nezavisimosti Respubliki Kazahstan [Saki Culture of Saryarka in the Context of Studying the Ethnosocial and Cultural Processes of Steppe Eurasia. Theses of Reports of the Round table Dedicated to the $20^{\text {th }}$ Anniversary of the Independence of the Republic of Kazakhstan]. Karaganda, pp. 199-205.

Morgunova N.L., Kraeva L.A., 2012. Kurgannaya gruppa Akoba II [Kurgan Group of Akoba II]. Arheologicheskie pamyatniki Orenburzh'ya [Archaeological Sites of the Orenburg Region], iss. 10. Orenburg, OSPU, pp. 156-199.

Moshkova M.G., 1972. Savromatskie pamyatniki severo-vostochnogo Orenburzh'ya [Sauromation Monuments of the North-eastern Orenburg Region]. Pamyatniki Yuzhnogo Priural'ya i Zapadnoy Sibiri sarmatskogo vremeni [Monuments of the South Urals and Western Siberia of the Sarmatian Time]. Materialy i issledovaniya po Arkheologii SSSR, no. 153. Moscow, Nauka Publ., pp. 49-78.

Myshkin V.N., 2014. Psalii s okonchaniyami v vide golov hishchnyh ptic u kochevnikov Samaro-Ural'skogo regiona [Cheek-Pieces with the Tips in the Form of Heads of Birds of Prey Among Nomads of the Samara-Ural Region]. Izvestiya SNC RAN [Bulletin of the Samara Scientific Center of the Russian Academy of Sciences], vol. 16, no. 3, pp. 308-313.

Myshkin V.N., Skarbovenko V.A., Hohlov A.A., 2000. Kochevniki Samarskogo Povolzh'ya vo vtoroy polovine I tysyacheletiya do n.e. [Nomads of the Samara Volga Region in the Second Half of the $1^{\text {st }}$ Millennium BC]. Rannesarmatskaya kul tura: formirovanie, razvitie, hronologiya. Materialy IV mezhdunarodnoy konferencii «Problemy sarmatskoy arheologii i istorii» [Early Sarmatian Culture: Formation, Development, Chronology. Materials of the IV international conference "Problems of Sarmatian archaeology and history"]. Samara, SSC RAS, pp. 71-84.

Ochir-Goryaeva M.A., 2012. Drevnie vsadniki stepey Evrazii [Ancient Horsemen of the Eurasian Steppes]. Moscow, Taus Publ. 472 p.

Pshenichnyuk A.H., 1995. Perevolochanskiy mogil'nik [Perevolochansk Cemetery]. Kurgany kochevnikov Yuzhnogo Urala [Kurgans of Nomads of the South Urals]. Ufa, Gilem Publ., pp. 62-96.

Pshenichnyuk A.H., 2012. Filippovka: Nekropol' kochevoy znati IV veka do n.e. na Yuzhnom Urale [Filippovka: Necropolis of the Nomadic Nobility of the $4^{\text {th }}$ Century BC in the South Urals]. Ufa, IHLL USC RAS. $280 \mathrm{p}$.

Sirotin S.V., 2015. Predmety konskoy sbrui iz nasypey kurganov rannih kochevnikov Yuzhnogo Urala (po materialam raskopok 2008-2013 godov) [Items of Horse Harness from the Kurgans of Early Nomads of the Southern Urals (Based on Materials from Excavations in 2008-2013)]. Etnicheskie vzaimodeystviya na Yuzhnom Urale: materialy VI Vserossiyskoy nauchnoy konferencii [Ethnic Interactions in the Southern Urals: Materials of the VI AllRussian Scientific Conference], Chelyabinsk, Chelyabinsk State Museum of Local Lore, pp. 247-255. 
Smirnov K.F., 1961. Vooruzhenie savromatov [The Armament of the Sauromats]. Materialy i issledovaniya po arkheologii, no. 101. Moscow, AS USSR. 170 p.

Smirnov K.F., 1964. Savromaty. Rannyaya istoriya i kul 'tura sarmatov [Sauromats. Early History and Culture of the Sarmatians]. Moscow, Nauka Publ. 380 p.

Smirnov K.F., 1975. Sarmaty na Ileke [Sarmatians on Ilek]. Moscow, Nauka Publ. 176 p.

Smirnov K.F., Petrenko V.G., 1963. Savromaty Povolzh'ya i Yuzhnogo Priural'ya [Sauromats of the Volga and Southern Urals Regions]. Svod arkheologicheskih istochnikov, iss. Д1-9. Moscow, AS USSR. 40 p.

Tairov A.D., 2004. Periodizatsiya pamyatnikov rannih kochevnikov Yuzhnogo Zaural'ya 7-2 vv. do n.e. [Periodization of the Monuments of the Early Nomads of the Southern Trans-Urals 7-2 Centuries BC]. Sarmatskie kul tury Evrazii: problemy regional'noy hronologii. Doklady k 5 mezhdunarodnoy konferencii «Problemy sarmatskoy arheologii i istorii» [Sarmatian Sultures of Eurasia: Problems of Regional Chronology. Reports for the $5^{\text {th }}$ International Conference "Problems of Sarmatian Archaeology and History"]. Krasnodar, pp. 3-21.

Tairov A.D., 2006. Saki Priaral'ya v stepyah Yuzhnogo Zaural'ya (po materialam mogil'nika Marovyy shlyah) [Saks of the Aral Sea in the Steppes of the Southern Trans-Urals (Based on Materials from the Marovy Shlyakh Cemetery)]. Yuzhnyy Ural i sopredel'nye territorii v skifo-sarmatskoe vremya: Sbornik statey k 70-letiyu Anatoliya Haritonovicha Pshenichnyuka [Southern Urals and Adjacent Territories in the Scythian-Sarmatian Time: Collection of Articles Dedicated to the $70^{\text {th }}$ Anniversary of Anatoly Kharitonovich Pshenichnyuk]. Ufa, Gilem Publ., pp. 76-91.

Tairov A.D., 2009. O transformatsii kul'tury kochevnikov Yuzhnogo Urala v kontse V - nachale IV vv. do n.e. [About Transformation of the Culture of the Southern Urals Nomads in the End V - Beginning IV Centuries BC]. Nizhnevolzhskiy Arheologicheskiy Vestnik [The Lower Volga Archaeological Bulletin], iss. 10, pp. 137-148.

Tairov A.D., Botalov S.G., 1988. Kurgan u s. Varna [Kurgan near the Village Varna]. Problemy arheologii UraloKazahstanskih stepey [Problems of Archaeology of the Ural-Kazakhstan Steppes]. Chelyabinsk, BSU, pp. 100-125.

Tairov A.D., Ul'yanov I.V., 2010. Sluchaynye nahodki predmetov rannego zheleznogo veka na Yuzhnom Urale [Accidental Finds of objects of the Early Iron Age in the Southern Urals]. Gorohovskie chteniya: materialy pervoy regional'noy muzeynoy konferencii [Gorokhov Readings: Materials of the First Regional Museum Conference]. Chelyabinsk, Chelyabinsk State Museum of Local Lore, pp. 210-216.

Treister M.Yu., 2012. Predmety vooruzheniya i konskogo snaryazheniya ahemenidskogo kruga iz Yuzhnogo Priural'ya [Items of Weapons and Horse Equipment of the Achaemenid Circle from the Southern Urals]. Vliyaniya ahemenidskoy kul'tury v Yuzhnom Priural'e (V-III vv. do n.e.) [Influences of the Achaemenid Culture in the Southern Urals (V-III centuries BC)]. Vol. I. Moscow, Taus Publ., pp. 115-116.

Treister M.Yu., Yablonskiy L.T., 2012. K voprosu ob absolyutnoy date mogil'nika Filippovka-I [To the Question of the Absolute Date of the Filippovka-I Cemetery]. Vliyaniya ahemenidskoy kul 'tury v Yuzhnom Priural'e (V-III vv. do n.e.) [Influences of the Achaemenid Culture in the Southern Urals (V-III Centuries BC)]. Vol. I. Moscow, Taus Publ., pp. 282-284.

Treister M.Yu., Shemahanskaya M.S., Yablonskiy L.T., 2012. Kompleksy s predmetami ahemenidskogo kruga mogil'nika Pokrovka [Complexes with Objects of the Achaemenid Circle at the Pokrovka Cemetery]. Vliyaniya ahemenidskoy kul'tury v Yuzhnom Priural'e (V-III vv. do n.e.) [Influences of the Achaemenid Culture in the Southern Urals (V-III centuries BC)]. Vol. II. Moscow, Taus Publ., pp. 85-156.

Fedorov V.K., Vasil’ev V.N., 2017. Uzdechnyy nabor s blyahami v vide ryb iz kurgana № 4 mogil'nika Sara v vostochnom Orenburzh'e [Bridle Sets with Plaques in the form of Fish from Sara Burial Mound № 4 in the eastern Orenburg Region]. Vestnik Yuzhnoural'skogo gosudarstvennogo universiteta. Seriya «Social'nogumanitarnye nauki» [Bulletin of the South Ural State University. Series "Social Sciences and the Humanities"], vol. 17, no. 1, pp. 54-62. DOI: 10.14529/ssh170109

Yablonskiy L.T., 2013. Zoloto sarmatskih vozhdey. Elitnyy nekropol'Flippovka I (po materialam raskopok 20042009 gg.): katalog kolleltsii [Gold of the Sarmatian Leaders. Elite Necropolis Flippovka I (Based on Materials from Excavations in 2004-2009): Collection Catalog]. Book 1. Moscow, IA RAS. 232 p. 
B.Н. Мышкин. Псалии с зооморфными изображениями у кочевников Самаро-Уральского региона

\section{Information About the Author}

Vladimir N. Myshkin, Candidate of History, Head of Archaeological Laboratory, Samara State Social and Pedagogical University, Leninskay St., 127, 443041 Samara, Russian Federation, vnm59@bk.ru, https://orcid.org/0000-0003-3489-6776

\section{Информация об авторе}

Владимир Николаевич Мышкин, кандидат исторических наук, заведующий археологической лабораторией, Самарский государственный социально-педагогический университет, ул. Ленинская, 127, 443041 г. Самара, Российская Федерация, vnm59@bk.ru, https://orcid.org/0000-0003-3489-6776 